\title{
Above- and below-ground competition between barley, wheat, lupin and vetch in a cereal and legume intercropping system
}

\author{
M. Mariotti*, A. Masoni*, L. Ercoli† and I. Arduini* \\ *Dipartimento di Agronomia e Gestione dell'Agroecosistema, Pisa University, Italy, and †Scuola Superiore \\ Sant'Anna, Pisa, Italy
}

\begin{abstract}
The effects of intercropping on dry weight (DW) of herbage and nitrogen $(\mathrm{N})$ nutrition of plants of two winter cereals, barley and wheat, and two legumes, white lupin and common vetch, were investigated, and above- and below-ground competition were separated in a fully factorial additive design. Intercropping increased DW compared with the sole species and the increase was higher for the cereals and lupin than for cereals and vetch intercropping systems. Above-ground competition for light reduced DW of cereals and lupin while it did not influence the DW of vetch. Processes involved in below-ground competition increased shoot growth of cereals and reduced shoot growth of legumes. $\mathrm{N}$ nutrition of cereals was enhanced by below-ground competition with legumes and $\mathrm{N}$ nutrition of vetch was enhanced by above-ground competition with cereals. Cereals had a higher competitive ability than legumes as a result of their below-ground competitive ability. The interaction between above- and below-competition is not predictable: negative, positive and no interaction (additivity) between different types of competition were found. In low-input intercropping systems, when a $\mathrm{N}$-fixing species is present, the mixture of the roots of components is important for the utilization of the soil resources and, when a climbing species is also present, the mixture of shoots can result in an increased utilization of light.
\end{abstract}

Keywords: above-ground competition, barley, belowground competition, common vetch, durum wheat, white lupin

Correspondence to: Marco Mariotti, Dipartimento di Agronomia e Gestione dell'Agroecosistema, Via S. Michele degli Scalzi 2, 56124 Pisa, Italy.

E-mail: marcom@agr.unipi.it

Received 22 May 2009; revised 20 July 2009

\section{Introduction}

In temperate climates, mixtures of annual legumes and winter cereals are commonly used for herbage production (Anil et al., 1998). Higher yields associated with intercropping occur when the component crops are complementary to each other, resulting in a more effective use of environmental resources, i.e. light, water and nutrients, compared with when grown alone. Higher yields have been documented for intercropping of beans and maize (Willey and Osiru, 1972), barley and peas (Hauggaard-Nielsen et al., 2001a; Chen et al., 2004), oats and vetches (Ercoli et al., 1997), wheat and peas (Ghaley et al., 2005), and wheat and beans (Ghanbari-Bonjar and Lee, 2003). The higher yield of a mixture may also be due to a facilitation process when one population affects the other population in a positive way (Vandermeer, 1989).

Intercropping of cereals and legumes is widely used in low-input agriculture because the mixture of nitrogen $(\mathrm{N})$-fixing and non- $\mathrm{N}$-fixing crop species provides complementarities in the utilization of resources (Hauggaard-Nielsen et al., 2003). In Mediterranean countries, intercropping of cereals with legumes has been a common cropping system in short-season rain-fed environments, especially because of their increased productivity and sustainability (Papastylianou, 2004). Recently, Mariotti et al. (2006) obtained superior yields and land equivalent ratios (LER) of 1.6 for lupins and 1.4 for vetches in intercropping systems with barley and wheat. Previous research, performed in a conventional farming system, reported lower or no yield advantage and LER of $1 \cdot 1-1 \cdot 2$ in Canada and of 0.95-1.19 in Spain, respectively, for lupins and wheat, and vetches and oats intercropping systems (Caballero et al., 1995; Jannasch and Martin, 1999).

The complementary use of resources occurs as a result of beneficial interactions between the intercropped species, such as (i) structural support for climbing species, which increases leaf area index and light interception (Robinson, 1969; Keating and Carberry, 1993), (ii) exploitation of a larger soil volume, achieved 
by higher length and density of roots or by different spatial distribution of roots (Hauggaard-Nielsen et al., 200lb; Li et al., 2006), (iii) increased efficiency of $\mathrm{N}$ fixation by legumes (Izaurralde et al., 1992; Senaratne et al., 1993; Jensen, 1996b), (iv) transfer of symbiotically fixed $\mathrm{N}$ from legume to non-legume intercropping (Jensen, 1996a; Xiao et al., 2004) and (v) reduced weed pressure and pathogen infection because of shading and higher biodiversity (Midmore, 1993; Mitchell et al., 2002).

The physical separation of above-ground competition from below-ground competition enables discrimination between the competition for light and the competition for nutrients and water. The relative strengths of aboveand below-competition are difficult to predict because they vary with availability of resources (Keddy, 1989; Cahill, 1999), ability of plants to change the allocation patterns of assimilates in order to increase organs that acquire the most limiting resources (Tilman, 1988; Wilson and Tilman, 1993, 1995), and with the plant's relative position within a size hierarchy (Cahill, 1999, 2002). Thus, from previous studies, it has emerged that responses to environmental changes are essentially species-specific (Cahill, 2002). In addition, the effect of full competition (above- and below-ground competition together) can be lower (negative interaction), equal (no interaction), or greater (positive interaction) than a combination of the separate effects of above- and below-ground competition (Cahill, 1999).

To better understand the mechanism of higher yields associated with cereal and legume intercropping, it is necessary to investigate (i) the nature of competition between components, (ii) the attributes that determine their competitive ability and (iii) the limiting resources for which crops compete. In this study, focused on annuals, the productivity, plant nutrition, specifically $\mathrm{N}$ uptake, and the competition in forage intercropping between two winter cereals and two legumes were assessed by separating the effects of competition for above-ground and below-ground resources. The species chosen, frequently cultivated in Mediterranean areas, were barley (Hordeum vulgare L.), durum wheat (Triticum durum Desf.), white lupin (Lupinus albus L.) and common vetch (Vicia sativa L.).

\section{Materials and methods}

The research was carried out in 2002-2003 and 20032004 at the experimental station of the Department of Agronomy and Agroecosystem Management of the University of Pisa, Italy, that is located at a distance of approximately $10 \mathrm{~km}$ from the sea $\left(43^{\circ} 41^{\prime} \mathrm{N}, 10^{\circ} 23^{\prime} \mathrm{E}\right)$ and $1 \mathrm{~m}$ a.s.l.

A 1:1 additive design was used, i.e. the density of each component in any mixture was the same as of the sole crop. The additive design was chosen because it allows interspecific competition to be studied without being confounded by the effects of intraspecific competition, as occurs in replacement designs (Snaydon, 1991).

The separation technique of Donald (1958), modified by Schreiber (1967), was used to separate the effect of above- and below-ground competition between cereals and legumes. The methodology has been utilized successfully to study the nature of root and shoot interactions between crops and weeds (Satorre and Snaydon, 1992), between component crops in intercropping for grain production (Tofinga et al., 1993), and for forage production (Thorsted et al., 2006).

The technique provides four combinations of above and below-ground competition: no competition between species - both shoots and roots separated (Figure la); above-ground competition - only roots separated (Figure 1b); below-ground competition only shoots separated (Figure lc); and full competition - neither shoots nor roots separated (Figure ld).

In both years, the experiment was a $2 \times 2 \times 2 \times 2$ factorial design with three replicates, where the factors were as follows: (i) two cereals; barley, cv. Emilia, and durum wheat, cv. Creso; (ii) two legumes; white lupin, cv. Multitalia, and common vetch, cv. Nitra; (iii) two above-ground competition levels, present or absent; (a)

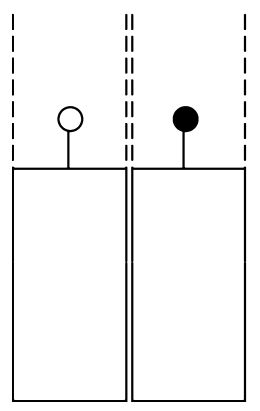

(b)

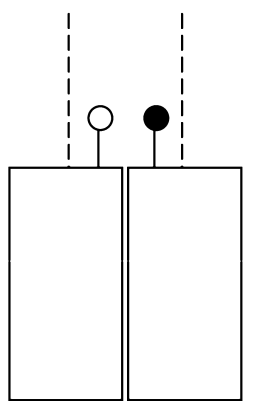

(c)

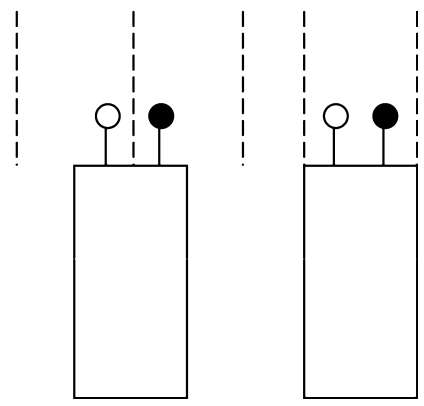

Figure I The planting arrangements of the intercropping systems between cereals (o) and legumes $(\bullet)$ to give:

(a) no competition; (b) above-ground competition; (c) below-ground competition; and (d) full competition. 
(iv) two below-ground competition levels, present or absent.

Barley and wheat differ in both shoot and root morphology, and in their competitive ability, when grown in intercropping (Cousens, 1996). White lupin is a legume with a high potential for grain production in Mediterranean areas and can be used in cereal and legume forage mixtures to increase their nutritive value (Jannasch and Martin, 1999; McKenzie and Spaner, 1999). Autumn-sown white lupin is characterized by a rosette stage during which the plant produces leaves without elongation of the corresponding internodes. The rosette stage ends when the main apex becomes floral, which depends on the vernalizing conditions and the vernalization requirements of the genotype under cultivation. Common vetch, an annual legume with a climbing growth habit and high concentrations of crude protein, is widely grown in mixtures with small-grain cereals for hay or herbage production (Lithourgidis et al., 2006). These two legumes differ in growth habit, in both shoot and root morphology, and in their N-fixing capacity (Huyghe, 1991; Caballero et al., 1996; Unkovich and Pate, 2000).

Plants were grown in rows, in aluminium-sided boxes $100 \mathrm{~cm}$ long $\times 10 \mathrm{~cm}$ wide $\times 30 \mathrm{~cm}$ deep, filled with a soil whose main physical and chemical properties were as follow: $33 \cdot 9 \%$ sand, $20 \cdot 8 \%$ silt and $45 \cdot 3 \%$ clay; $\mathrm{pH}$ of $7 \cdot 2$, organic matter content (Walkley and Black method) of $18.5 \mathrm{~g} \mathrm{~kg}^{-1}$, total $\mathrm{CaCO}_{3}$ content (Scheibler method) of $11.2 \mathrm{~g} \mathrm{~kg}^{-1}$, total $\mathrm{N}$ content (Kjeldhal method) of $0.9 \mathrm{~g} \mathrm{~kg}^{-1}$, available P content (Olsen method) of $43 \mathrm{ppm}$ and available $\mathrm{K}$ content (ammonium acetate test method) of $167 \mathrm{ppm}$. The boxes were oriented in a N-S direction and the aerial partitions were made of reflective material. Sowing took place on 31 October 2002 and 25 October 2003, at densities equivalent to 400 viable seeds per $\mathrm{m}^{2}$ for barley and durum wheat, 100 viable seeds per $\mathrm{m}^{2}$ for white lupin, and 200 viable seeds per $\mathrm{m}^{2}$ for common vetch, either for sole crops and intercropping. The symbiosis between white lupin and its specific rhizobium (Rhizobium lupini) was promoted by mixing the seeds of white lupin with slightly wet soil where a white lupin crop had been cultivated in the previous year. No use of fertilizers or herbicide was made. To prevent any below-ground competition for water, all boxes were watered daily to field capacity with a dripirrigation system. The experiment was netted to exclude birds.

Sole crops and intercropping systems were harvested at the dough-ripening stage of cereals (decimal code 83-85 of the scale of Zadoks et al., 1974), while white lupin and common vetch were harvested at the podfilling stage. Within each species, no difference in phenological stage was recorded between sole crops and intercropping systems. The herbage grown in each box was cut at ground level and was separated into cereals and legumes. Winter cereal and legume plants were divided into stems plus leaves (referred to as the vegetative part in the rest of the text), spikes or pods (reproductive part), and roots. Throughout the rest of the text, 'shoot' refers to the sum of the vegetative and reproductive plant parts. The roots were separated from the soil by gently washing with water. Plant parts were oven-dried for determination of dry weight (DW) at $75^{\circ} \mathrm{C}$ to constant weight and analysed for $\mathrm{N}$ concentration (NC) by the microKjeldahl method. $\mathrm{N}$ yield (NY) was obtained by multiplying NC by DW.

The resource complementarity was measured by the relative total yield (RYT) and, according to De Wit and Van Den Bergh (1965), was expressed as RYT $=\left(Y_{\mathrm{ab}} /\right.$ $\left.Y_{\mathrm{aa}}\right)+\left(Y_{\mathrm{ba}} / Y_{\mathrm{bb}}\right)$, where $Y_{\mathrm{ab}}$ is the yield (mass of plant material per unit land area) of crop ' $a$ ' growing in association with crop ' $b$ ' in intercropping, $Y_{\mathrm{ba}}$ is the yield of crop b growing in association with crop a in intercropping, and $Y_{\mathrm{aa}}$ and $Y_{\mathrm{bb}}$ are the yields of crop a and crop $b$ respectively in sole cropping (i.e. no competition).

The competitive ability of a crop in intercropping, relative to the other, was measured by the Competitive Balance Index (Cb) and, according to Wilson (1988), was expressed as $\mathrm{Cb}=\ln \left[\left(Y_{\mathrm{ab}} / Y_{\mathrm{aa}}\right) /\left(Y_{\mathrm{ba}} / Y_{\mathrm{bb}}\right)\right]$.

\section{Statistical analyses}

Data were analysed statistically by analysis of variance (ANOVA), using COSTAT statistical package (version 6.4, CoHort Software, Monterey, CA, USA). For each cereal and legume intercropping system, ANOVAs on plant DW, NC and NY were performed as a $2 \times 2 \times 2$ factorial design (i.e. 2 years $\times$ two levels of above-ground competition $\times$ two levels of below-ground competition) with three replicates. Anovas on RYT and $\mathrm{Cb}$ were performed as a $2 \times 3$ factorial (i.e. 2 years $\times$ three types of competition - above-, below- and full competition) with three replicates.

No statistically significant year effect or year $\times$ competition treatment interactions were recorded, so data reported are the means of the 2 years. The treatments received an optimal water supply in both years, which probably caused the effect of year to be non-significant. Significantly different means were separated at $P<0.05$ by the least significant difference test (Snedecor and Cochran, 1980).

\section{Results}

\section{Resource complementarity}

The DW of the four sole species, obtained in conditions of no competition between components, were similar, 

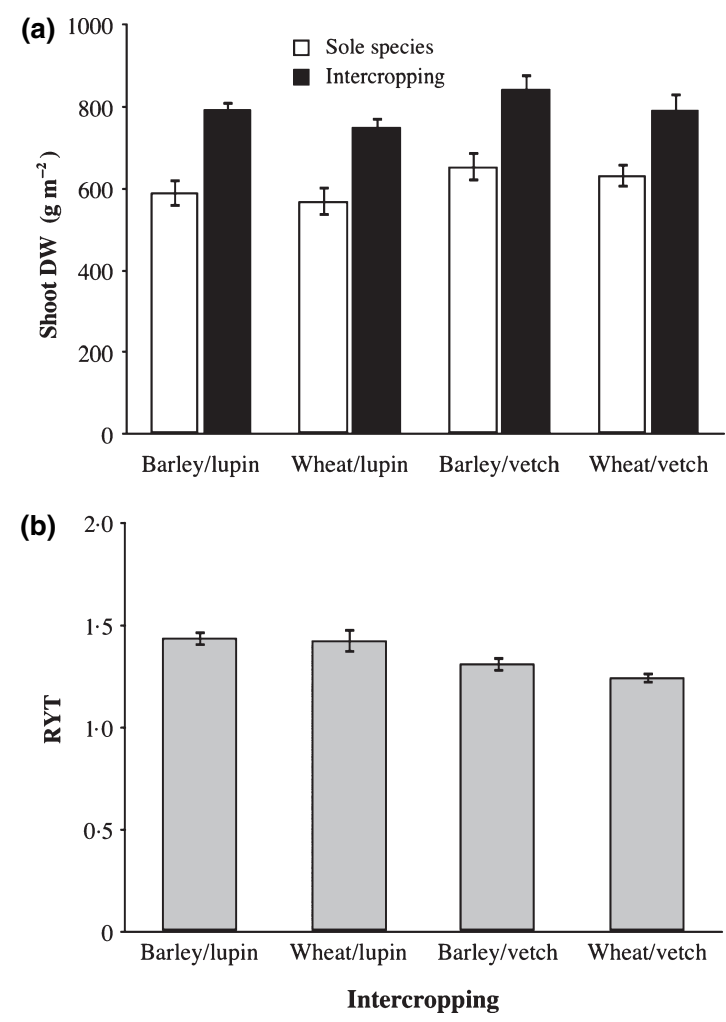

Figure 2 (a) Shoot dry weight (DW) and (b) relative total yield (RYT) of barley and white lupin (lupin), wheat and white lupin, barley and common vetch (vetch), and wheat and common vetch, intercropping systems. Values for intercropping systems were obtained in conditions of full competition. Shoot DW data were calculated on the basis of the same surface area: the values for sole species were averaged and the values for intercropping systems were pooled. Vertical bars indicate standard error of mean.

ranging from $5 \cdot 7 \mathrm{t} \mathrm{ha}^{-1}$ recorded for wheat and white lupin to $6.5 \mathrm{t} \mathrm{ha}^{-1}$ for barley and common vetch (Figure 2a). In conditions of full competition between components, shoot DW of intercropping systems was higher than for sole species with the highest difference proportionately being recorded in the barley and white lupin intercropping system $(+0 \cdot 35)$ and the lowest in wheat and common vetch intercropping system $(+0 \cdot 25)$. To make a correct comparison, data in Figure $2 \mathrm{a}$ were calculated on the same surface area, and not on a species basis, so the sole species values were averaged and the intercropping values were pooled. Resource complementarity of intercropping was evidenced by RYT values that were always higher than $1 \cdot 0$, with slightly higher values for the cereals and white lupin intercropping systems than for the cereals and common vetch intercropping systems (Figure $2 \mathrm{~b}$ ).

\section{Dry weight of cereals}

Above-ground competition with white lupin reduced shoot and root DWs of barley by proportionately 0.36 and 0.29 and shoot and root DWs of wheat by 0.41 and $0 \cdot 43$, with respect to treatments excluding competition (Figure 3). Below-ground competition with white lupin increased shoot DWs of barley and wheat by 0.26 and $0 \cdot 14$ and reduced root DWs of barley and wheat by $0 \cdot 10$ and $0 \cdot 18$ respectively. Above-ground competition with common vetch reduced shoot and root DWs of both cereals by about 0.45 while below-ground competition increased slightly shoot DW and reduced root DW of both cereals.

The effect of full competition with white lupin was lower than expected on the basis of the separate effects of above- and below-ground competition (the above$\times$ below-ground interaction was negative), leading to a slight increase in shoot DWs of barley and wheat $(+0 \cdot 11$ and $+0 \cdot 04$ respectively) and to a modest decrease in root DWs $(-0.08$ and $-0 \cdot 22)$. Full competition with common vetch gave no evidence of interaction between aboveand below-ground competition.

Above-ground competition did not modify allocation patterns of biomass between roots and shoots of cereals. On the contrary, below-ground competition with both legumes modified the root:shoot ratios of cereals from about 0.26 to 0.20 in barley and from 0.21 to 0.15 in wheat (data not shown).

\section{Dry weight of legumes}

Legumes responded to competition from cereals in a different way. In white lupin plants, shoot and root DWs were reduced by competition with cereals (Figure 3). Above-ground competition with both cereals reduced shoot and root DWs of white lupin proportionately by about $0 \cdot 23$ and $0 \cdot 18$ respectively. Belowground competition with barley reduced shoot DW of white lupin by 0.36 and root DW of white lupin by 0.15 , while below-ground competition with wheat reduced shoot and root DWs of white lupin by 0.26 and 0.11 respectively. The effect of above- and below-ground competition together (full competition) was greater than a mathematical combination of the separate effects (positive interaction): full competition with cereals reduced shoot and root DWs of white lupin by 0.65 and 0.55 respectively. Below-ground and full competition with cereals reduced shoot DW more than root DW, so that the root:shoot ratio was increased (from 0.35 to about 0.48 with both cereals).

In common vetch plants, there was no interaction between above- and below-ground competition. Above-ground competition with barley and wheat did not modify significantly the DWs of shoot and root, 

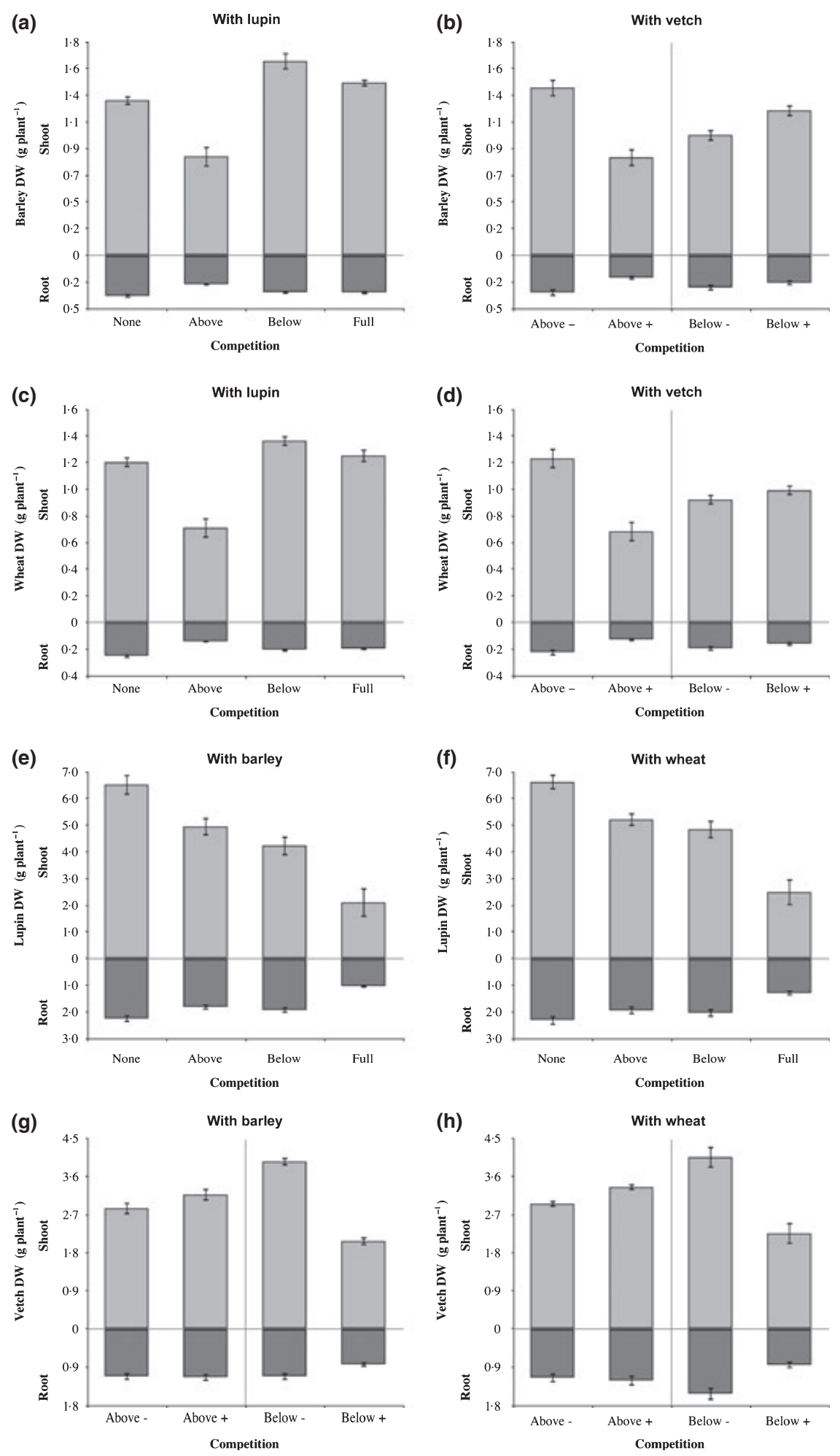

Figure 3 Shoot and root dry weight (DW) of barley, wheat, white lupin (lupin) and common vetch (vetch) as affected by the interaction [(a), (c), (e) and (f)], or by the mean effect [(b), (d), (g) and (h)] of above- and below-ground competition. Vertical bars indicate standard error of mean. 
Table I Proportion of shoot mass represented by the pods, number of pods per plant and dry weight (DW) per pod of legumes, as affected by types of competition with cereals (barley and wheat).

\begin{tabular}{|c|c|c|c|c|c|c|c|}
\hline \multirow[b]{2}{*}{ Legume } & \multirow[b]{2}{*}{$\begin{array}{l}\text { Type of } \\
\text { competition }\end{array}$} & \multicolumn{3}{|c|}{ With barley } & \multicolumn{3}{|c|}{ With wheat } \\
\hline & & $\begin{array}{l}\text { Proportion } \\
\text { as pods }\end{array}$ & $\begin{array}{l}\text { No. pods } \\
\text { plant }^{-1}\end{array}$ & $\begin{array}{l}\text { DW per } \\
\text { pod }(\mathrm{mg})\end{array}$ & $\begin{array}{l}\text { Proportion } \\
\text { as pods }\end{array}$ & $\begin{array}{l}\text { No. pods } \\
\text { plant }^{-1}\end{array}$ & $\begin{array}{l}\text { DW per } \\
\text { pod }(\mathrm{mg})\end{array}$ \\
\hline \multirow[t]{4}{*}{ White lupin } & Above- & $0 \cdot 158^{\mathrm{a}_{*}}$ & $4 \cdot 3^{\mathrm{a}}$ & $222 \cdot 2^{a}$ & $16 \cdot 0^{\mathrm{a}}$ & $4 \cdot 3^{\mathrm{a}}$ & $225 \cdot 0^{a}$ \\
\hline & Above+ & $0 \cdot 105^{\mathrm{b}}$ & $1.5^{\mathrm{b}}$ & $251 \cdot 9^{a}$ & $8 \cdot 9^{\mathrm{b}}$ & $1.5^{\mathrm{b}}$ & $234 \cdot 6^{\mathrm{a}}$ \\
\hline & Below- & $0 \cdot 226^{\mathrm{a}}$ & $3 \cdot 2^{\mathrm{a}}$ & $413 \cdot 9^{a}$ & $21 \cdot 2^{\mathrm{a}}$ & $3 \cdot 3^{\mathrm{a}}$ & $395 \cdot 7^{\mathrm{a}}$ \\
\hline & Below+ & $0.037^{\mathrm{b}}$ & $2 \cdot 6^{\mathrm{a}}$ & $60 \cdot 2^{\mathrm{b}}$ & $3 \cdot 7^{\mathrm{b}}$ & $2 \cdot 5^{\mathrm{b}}$ & $64 \cdot 0^{\mathrm{b}}$ \\
\hline \multirow[t]{4}{*}{ Common vetch } & Above- & $0 \cdot 144^{\mathrm{b}}$ & $4 \cdot 7^{\mathrm{b}}$ & $88 \cdot 8^{\mathrm{b}}$ & $15 \cdot 2^{\mathrm{b}}$ & $4 \cdot 8^{\mathrm{b}}$ & $95 \cdot 4^{\mathrm{b}}$ \\
\hline & Above+ & $0 \cdot 262^{\mathrm{a}}$ & $6 \cdot 1^{\mathrm{a}}$ & $137 \cdot 1^{\mathrm{a}}$ & $27 \cdot 5^{\mathrm{a}}$ & $6 \cdot 4^{\mathrm{a}}$ & $145 \cdot 7^{\mathrm{a}}$ \\
\hline & Below- & $0 \cdot 226^{\mathrm{a}}$ & $6 \cdot 5^{\mathrm{a}}$ & $136 \cdot 7^{\mathrm{a}}$ & $23 \cdot 0^{\mathrm{a}}$ & $6 \cdot 8^{\mathrm{a}}$ & $137 \cdot 5^{\mathrm{a}}$ \\
\hline & Below+ & $0 \cdot 179^{\mathrm{b}}$ & $4 \cdot 3^{\mathrm{b}}$ & $89 \cdot 2^{\mathrm{b}}$ & $19 \cdot 7^{\mathrm{b}}$ & $4 \cdot 3^{\mathrm{b}}$ & $103 \cdot 7^{\mathrm{b}}$ \\
\hline
\end{tabular}

*In each legume and type of competition, values followed by the same letter are not significantly different at $P \leq 0 \cdot 05$.

while below-ground competition reduced shoot DW proportionately by about $0 \cdot 45$ and root DW by about $0 \cdot 35$ (Figure 3). Below-ground competition with both cereals increased the root:shoot ratio of common vetch from $0 \cdot 37$ to $0 \cdot 44$.

Competition from cereals negatively affected the reproductive plant parts of white lupin more than the vegetative ones, owing to a reduced partitioning of dry matter to pods (Table 1). The effect was higher with below-ground than with above-ground competition and was caused by DW per pod for the former and by number of pods per plant for the latter. In the common vetch, above-ground competition with cereals increased the reproductive parts as a proportion of the total plant, owing to an increase in the proportion of shoot DW represented by the pods from $0 \cdot 15$ to $0 \cdot 27$ (Table 1): the effect was caused by an increase in the DW per pod and by the number of pods per plant. In the common vetch, below-ground competition with both cereals reduced the contribution of pods to total shoot DW, an effect that was caused by the decrease in both DW per pod and number of pods per plant.

\section{Competitive ability}

Cereals had a higher below-ground competitive ability than legumes, and legumes had a higher above-ground competitive ability than cereals (Table 2 ). In conditions of full competition, the competitive ability of cereals was higher than that of white lupin but the same as that of common vetch. Values for barley were a little higher than values for wheat with all types of competition.

\section{Nitrogen yield}

Nitrogen concentration showed little variation between the different types of competition. Consequently, the
Table 2 Competitive balance index (on dry weight basis) of four intercropping systems as affected by type of competition.

\begin{tabular}{|c|c|c|c|c|}
\hline \multirow[b]{2}{*}{$\begin{array}{l}\text { Type of } \\
\text { competition }\end{array}$} & \multicolumn{4}{|c|}{ Intercropping system } \\
\hline & $\begin{array}{l}\text { Barley } \\
\text { and } \\
\text { white } \\
\text { lupin }\end{array}$ & $\begin{array}{l}\text { Wheat } \\
\text { and } \\
\text { white } \\
\text { lupin }\end{array}$ & $\begin{array}{l}\text { Barley } \\
\text { and } \\
\text { common } \\
\text { vetch }\end{array}$ & $\begin{array}{l}\text { Wheat } \\
\text { and } \\
\text { common } \\
\text { vetch }\end{array}$ \\
\hline Above & $-0 \cdot 17^{\mathrm{c}_{*}}$ & $-0 \cdot 30^{c}$ & $-0 \cdot 61^{c}$ & $-0 \cdot 70^{c}$ \\
\hline Below & $0 \cdot 67^{\mathrm{b}}$ & $0 \cdot 43^{\mathrm{b}}$ & $0.93^{\mathrm{a}}$ & $0 \cdot 72^{\mathrm{a}}$ \\
\hline Full & $1 \cdot 24^{\mathrm{a}}$ & $1 \cdot 01^{\mathrm{a}}$ & $0 \cdot 16^{\mathrm{b}}$ & $-0 \cdot 06^{\mathrm{b}}$ \\
\hline
\end{tabular}

*In each column, values followed by the same letter are not significantly different at $P \leq 0 \cdot 05$.

pattern of NY was similar to that of DW. Significant variations, however, were recorded in cereals and white lupin intercropping systems: The NC of cereals was increased by below-ground competition with white lupin, whereas NC of white lupins was decreased by all type of competition with cereals (Table 3).

Because of the combined effect of DW and $\mathrm{N}$ concentration, below-ground and full competition enhanced $\mathrm{NY}$ of barley by +5 and $+2 \mathrm{mg} \mathrm{N}$ plant $^{-1}$ respectively, for below-ground and full competition and $\mathrm{NY}$ of wheat by +3 and $+2 \mathrm{mg} \mathrm{N}$ plant $^{-1}$, and reduced that of white lupin, compared with treatments excluding competition (Figure 4).

In the cereals and common vetch intercropping system, the above-ground competition reduced NY of both cereals by about $4 \mathrm{mg} \mathrm{N}$ plant ${ }^{-1}$ while it enhanced $\mathrm{NY}$ of common vetch by $8 \mathrm{mg} \mathrm{N}$ plant $^{-1}$ with barley and $12 \mathrm{mg} \mathrm{N}$ plant $^{-1}$ with wheat as a companion species (Figure 4). With below-ground competition, NY of barley and wheat was unchanged, with respect to treatments excluding competition, and NY of common vetch was lower. 
Table 3 Cereals and white lupin intercropping systems: nitrogen concentration $\left(\mathrm{g} \mathrm{kg}^{-1} \mathrm{DM}\right)$ of shoots of barley, wheat and white lupin as affected by type of competition.

\begin{tabular}{|c|c|c|c|c|}
\hline \multirow[b]{3}{*}{$\begin{array}{l}\text { Type of } \\
\text { competition }\end{array}$} & \multicolumn{4}{|c|}{ Nitrogen concentration } \\
\hline & \multirow[b]{2}{*}{ Barley } & \multirow[b]{2}{*}{ Wheat } & \multicolumn{2}{|c|}{ White lupin } \\
\hline & & & $\begin{array}{l}\text { With } \\
\text { barley }\end{array}$ & $\begin{array}{l}\text { With } \\
\text { wheat }\end{array}$ \\
\hline None & $7 \cdot 9^{\mathrm{b} *}$ & $7 \cdot 3^{\mathrm{b}}$ & $15 \cdot 7^{\mathrm{a}}$ & $16 \cdot 1^{\mathrm{a}}$ \\
\hline Above & $8 \cdot 1^{\mathrm{b}}$ & $7 \cdot 6^{\mathrm{b}}$ & $13 \cdot 2^{\mathrm{b}}$ & $14 \cdot 4^{\mathrm{b}}$ \\
\hline Below & $9 \cdot 2^{\mathrm{a}}$ & $8 \cdot 7^{\mathrm{a}}$ & $11 \cdot 5^{\mathrm{b}}$ & $12 \cdot 5^{\mathrm{c}}$ \\
\hline Full & $8 \cdot 3^{\mathrm{ab}}$ & $8 \cdot 4^{\mathrm{a}}$ & $9 \cdot 0^{c}$ & $9 \cdot 9^{\mathrm{d}}$ \\
\hline
\end{tabular}

*In each column, values followed by the same letter are not significantly different at $P \leq 0.05$.

\section{Discussion}

Intercropping is an old and widespread practice in agriculture which is based on the management of plant interactions to maximize production of DW (Trenbath, 1974; Ofori and Stern, 1987). Higher yields result from resource complementarity producing more efficient resource use via niche separation (Wilson, 1988) or facilitative interactions between components (Hauggaard-Nielsen and Jensen, 2005).

In this study, all intercropping systems had higher shoot DWs than sole species and consequently RYT values greater than $1 \cdot 0$, regardless of the type of competition and the species, indicating that the complementary facilitation dominated over the competitive interference. This is important because the research was carried out without the application of fertilizer and, in this situation, enhanced productivity of herbage with a high nutritive value is desirable. The results in this study are comparable to increases in yield observed in other experiments with the same cereal and legume intercropping species (Jannasch and Martin, 1999; Mariotti et al., 2006; Dhima et al., 2007).

Although intercropping always gave higher yields than sole species, the single components of the mixture responded to the types of competition in different ways, and often with a reduction in their DW. Indeed, RYT values higher than $1 \cdot 0$ and lower than $2 \cdot 0$ indicate that resource complementarity and competition interference between companion crops occurred at the same time.

Barley and wheat showed similar behaviour in intercropping systems, although response in yield and competitive ability of barley were slightly higher than those of wheat, i.e. barley gained slightly more advantage and suffered slightly less competition from legumes than wheat. Growth characteristics that allow more rapid establishment of barley plants than wheat plants, such as an earlier rate of leaf production, are likely to be the determining factors leading to the observed dominance exerted by this species when intercropped (Cousens, 1996; Jensen, 1996b).

Above-ground competition reduced the DW of the cereals and white lupin, with the relative magnitude of this effect being greatest in wheat and lowest in white lupin while it did not influence the DW of common vetch. However, in all species, above-ground competition did not alter root:shoot ratios, because modifications in biomass allocation to roots were similar to those in shoots. This indicates that the lowered carbohydrate synthesis arising from limited light availability reduced root and shoot growth equally.

Higher yields by mixtures have often been attributed to a more efficient use of light by their canopy (Keating and Carberry, 1993). Among above-ground factors, the components that affect the light regime of plant canopies are the amount and quality of incident radiation, the canopy architecture (LAI and leaf orientation) and the optical properties of leaves (pigment content and absorbance of incident radiation) (Ercoli et al., 1993; Sinoquet and Caldwell, 1995).

The reductions in DW reported for cereals and white lupin with above-ground competition are probably related to the limited light intercepted by the reduced canopies, and similar results for cereals have been obtained by Tofinga et al. (1993). Also in white lupin Strydhorst et al. (2008) reported that the amount of light available at the top of the canopy was reduced proportionately by about 0.50 in the presence of barley. In addition, considering that $\mathrm{NC}$ is closely related to chlorophyll concentration, absorbance of incident radiation and photosynthetic capacity in a wide range of crops (Sinclair and Horrie, 1989; Ercoli et al., 1993), it is argued from the data reported in Table 3 that photosynthetic capacity of white lupins was also reduced by above-ground competition. The DWs of common vetch were not modified by above-ground competition, probably because companion cereals provide structural support and contribute to increase light interception (Ercoli et al., 1997).

Conversely, below-ground competition increased shoot growth of cereals and decreased that of legumes, while it reduced root growth in all species. Thus, belowground competition modified the pattern of biomass allocation in the plant, and the root:shoot ratio decreased in cereals and increased in legumes. A decrease in root:shoot ratio is generally considered an indicator of an increase of availability of soil nutrients, as plants adjust their root weight in response to environmental conditions to maximize relative growth rate (Martin and Field, 1984; Aerts et al., 1991). In cereals, the effect was probably because of the facilitative effects of mixing their roots with those of 

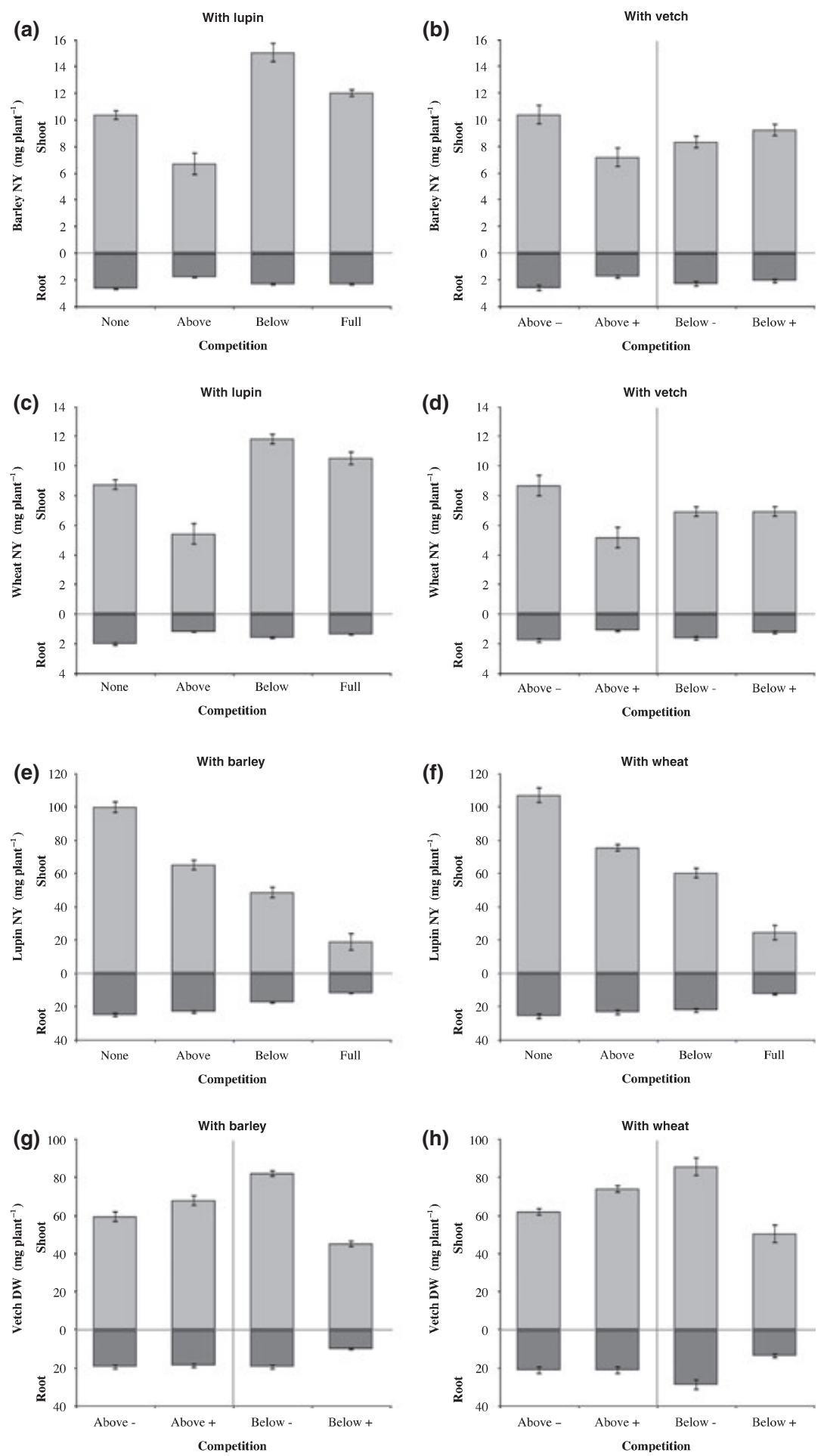

Figure 4 Shoot and root nitrogen yield (NY) of barley, wheat, white lupin (lupin) and common vetch (vetch) as affected by the interaction [(a), (c), (e) and (f)], or by the mean effect [(b), (d), (g) and (h)] of above- and below-ground competition. Vertical bars indicate standard error of mean. 
leguminous plants, mainly arising from the transfer of $\mathrm{N}$ from the legumes (Xiao et al., 2004). In this study, although it was not possible to quantitatively determine the $\mathrm{N}$ transfer from legumes to cereals, either directly or indirectly, NY of cereals was increased by 10-20 $\mathrm{kg} \mathrm{N} \mathrm{ha}{ }^{-1}$ when cereal roots were intermingled with those of legumes. Other possible facilitation effects recorded for roots of white lupin have been reported by Suong et al. (2005). In the legumes, the increase in the root:shoot ratio because of below-ground competition indicates the responses of the plants to the lower fertility conditions caused by the roots of the cereals.

The balanced-growth hypothesis of Shipley and Meziane (2002), which states that plants preferentially allocate resources to the organs acquiring the most limiting resources, is confirmed by the results obtained with below-ground competition. On the contrary, the data on above-ground competition do not support this hypothesis, as the root:shoot ratio was unchanged in all cereal and legume intercropping systems. Crucial to this hypothesis is the assumption that light interception and nutrient uptake are proportional to leaf and root, and shoot biomasses, although light interception depends on leaf area and nutrient uptake depends on root surface area. Consequently, it is not possible to exclude morphological adaptative strategies in the plants.

In the legumes, the competition modified the biomass allocation between reproductive and vegetative organs, with generally negative effects being more pronounced in white lupin than in common vetch, and with below-ground competition greater than above-ground competition. Other authors have reported that white lupin responds to environmental stress primarily by decreasing reproductive organs (Herbert, 1977; Withers, 1979), and similar results have been reported for intercropping with white lupin (Carruthers et al., 2000). A greater effect of belowground than above-ground competition on inflorescence was also reported by Tofinga et al. (1993). In common vetch, a species with a climbing growth habit, an increase in the incidence of pods was observed with above-ground competition, probably because of the greater amount of radiation intercepted by lower parts of the stem when a cereal plant provided physical support (Ercoli et al., 1997). The greater sink strength (through increased number and mass of pods) that resulted, promoted a higher $\mathrm{N}$ demand and was probably the cause of the enhanced NY of common vetch (Figure 4).

Nitrogen nutrition of legumes requires some consideration. In previous studies carried out with full competition between legume and non-legume intercropping, it emerged that the non-legume was found to be more competitive than the legume for soil $\mathrm{N}$, forcing the legume to rely mainly on $\mathrm{N}_{2}$ fixation for its $\mathrm{N}$ nutrition. In these conditions, the legume's proportion of $\mathrm{N}$ derived from the atmosphere increases as a result of intercropping with a non-legume crop, although the amount of $\mathrm{N}$ accumulated in the plant will be lowered (Danso et al., 1987; Schmidtke et al., 2004). Clearly these results were caused by below-ground and not by above-ground competition (Tofinga et al., 1993). In this study, although no data about $\mathrm{N}_{2}$ fixation were collected, these findings can help to explain the $\mathrm{N}$ nutrition of common vetch, because in this species it seems that competition did not reduce the ability to obtain $\mathrm{N}$ from soil and/or from $\mathrm{N}_{2}$ fixation, and the competition effect on the $\mathrm{N}$ nutrition appeared indirect, because of variations in DW. Instead in white lupin, all types of competition from cereals reduced both NC and NY: thus it seems that white lupin and cereals competed highly for soil $\mathrm{N}$, but also that competition reduced the $\mathrm{N}_{2}$-fixing capacity of the legume.

Cereals had higher below-ground competitive ability than legumes and this was apparently not caused by differences in allocation of biomass to the roots, and legumes presented higher above-ground competitive ability than cereals, again not apparently because of differences in shoot allocation: no clear pattern emerges on the relative cause and effect between competitive ability and biomass allocation pattern. Higher belowground competitive ability of cereals than legumes can be the result of the much finer roots of cereals (Martin and Snaydon, 1982), resulting in more efficient exploration of the soil volume, a faster development of roots (Hauggaard-Nielsen et al., 2001b) and a higher N-uptake capacity (Jensen, 1996a; KarpensteinMachan and Stuelpnagel, 2000). The higher aboveground competitive ability of legumes, compared with cereals, can be ascribed to the climbing growth habit of common vetch and to the greater size of the shoots of white lupin (about six times larger than the shoot of cereals - see Figure 3). As mentioned before, the competitive ability of a plant may not be directly correlated to the pattern of allocation of biomass because plants grown in conditions of limiting resources may adopt adaptative strategies, without modifying their allocation of DW (Aerts et al., 1991; Grime et al., 1991).

Above- and below-ground competition can have additive and non-additive effects on plant growth and the non-additive effect may be positive or negative (Cahill, 1999). A negative interaction results when one type of competition mitigates the negative effect of the other type of competition. In this study, negative interaction was found in cereals that compete belowground with white lupin, probably because cereals compete better for the aerial space with legumes when they have intermingled roots because, in these conditions, the increased $\mathrm{N}$ nutrition of cereals (Table 2 and 
Figure 4), arising from a real below-ground facilitation, allows an increase in shoot growth, thus reducing the severity of above-ground competition.

A positive interaction was also found between aboveand below-ground competition. This occurred in white lupin intercropped with cereals. Positive interaction can result because below-ground competition reduced NC and NY in white lupin (Table 2). In these conditions, there was possibly a lower photosynthetic capacity of the leaves and thus the negative effect of the shading (above-ground competition) was enhanced (Cahill, 2002).

There was no interaction between above- and belowground competition when the cereals were intercropped with common vetch. The $\mathrm{N}$ transfer from common vetch to graminaceous plants is low and sometimes uncertain (Papastylianou and Danso, 1991; Kurdali et al., 1996) and the climbing growth habit of legumes can confer a high above-ground competitive ability (Tofinga et al., 1993). In these conditions, where a low below-ground facilitation and a high aboveground competition from the companion species do occur, the mitigation effect of one type of competition (below-ground) on the other type (above-ground) is not possible.

In conclusion, this study showed that competition had different effects on the different species and that the interaction between above- and below-ground competition varied among species from negative to positive synergy and additivity. Thus, the distinct differences in the canopy structure and root activity of different components of intercropping systems can affect the relative importance of above- and belowground competition, and their interaction. Interspecific competition and facilitation can exist simultaneously. The results suggest that, in low-input intercropping systems, when a $\mathrm{N}$-fixing species is present, the intermingling of root of the component species is important for utilization of soil nutrients, while there is little evidence for increased utilization of light because of intermingling of shoots, although the species with climbing growth habit, like common vetch, can benefit. Modifying sowing time of the components (delaying the seeding time of the species with the higher competitive ability) and/or the design of the intercropping system, such as modifying the seeding ratio or row configuration, could possibly reduce the competition and enhance facilitation effects, with increased yield and nutritive value of the herbage.

\section{Acknowledgments}

This work was funded by University of Pisa (Fondi di Ateneo).

\section{References}

Aerts R., Boot R.G.A. and van der Aart P.J.M. (1991) The relationship between above- and below-ground biomass allocation patterns and competitive ability. Oecologia, 87, 551-559.

Anil L., PArk J., Phipps R.H. and Miller F.A. (1998) Temperate intercropping of cereals for forage: a review of the potential for growth and utilization with particular reference to the UK. Grass and Forage Science, 53, 301-317.

Caballero R., Goicoechea E.L. and Hernaiz P.J. (1995) Forage yields and quality of common vetch and oat sown at varying seeding ratios and seeding rates of vetch. Field Crops Research, 41, 135-140.

Caballero R., Rebolè A., Barro C., Alzueta C., Trevino J. and Garcia C. (1996) Farming practices and chemical basis for a proposed quality standard of vetchcereal hays. Field Crop Research, 47, 181-1894.

Cahill J.F. (1999) Fertilization effects on interactions between above- and below-ground competition in an old field. Ecology, 80, 466-480.

CAHill J.F. (2002) Interactions between root and shoot competition vary among species. Oikos, 99, 101-112.

Carruthers K., Prithiviraj B., Fe Q., Cloutier D., MARTIN R.C. and SMith D.L. (2000) Intercropping corn with soybean, lupin and forages: yield component responses. European Journal of Agronomy, 12, 103-1 15.

Chen C., Westcott M., Neill K., Wichman D. and KNox M. (2004) Row configuration and nitrogen application for barley-pea intercropping in Montana. Agronomy Journal, 96, 1730-1738.

Cousens R.D. (1996) Comparative growth of wheat, barley and annual ryegrass (Lolium rigidum) in monoculture and mixture. Australian Journal of Agricultural Research, 47, 449-464.

Danso S.K.A., Zapata F., Hardarson G. and Fried M. (1987) Nitrogen fixation in faba beans as affected by plant population density in sole or intercropped systems with barley. Soil Biology and Biochemistry, 19, 411-415.

De Wit C.T. and Van Den Bergh J.P. (1965) Competition between herbage plants. Netherlands Journal of Agricultural Science, 13, 212-221.

Dhima K.V., Lithourgidis A.S., Vasilakoglou I.B. and Dordas C.A. (2007) Competition indices of common vetch and cereal intercrops in two seeding ratios. Field Crops Research, 100, 249-256.

Donald C.M. (1958) The interaction of competition for light and for nutrients. Australian Journal of Agricultural Research, 9, 421-435.

Ercoli L., Mariotti M., Masoni A. and Massantini F. (1993) Relationship between nitrogen and chlorophyll content and spectral properties in maize leaves. European Journal of Agronomy, 2, 113-117.

Er coli L., Mariotti M. and Masoni A. (1997) Radiation interception of oat/vetch intercrop. Rivista di Agronomia, 31, 658-665.

Ghaley B., Hauggaard-Nielsen H., Høgh-Jensen H. and JENSEN E. (2005) Intercropping of wheat and pea as influenced by nitrogen fertilization. Nutrient Cycling in Agroecosystems, 73, 201-212. 
Ghanbari-Bonjar A. and Lee H.C. (2003) Intercropped wheat (Triticum aestivum L.) and bean (Vicia faba L.) as a whole-crop forage: effect of harvest time on forage yield and quality. Grass and Forage Science, 58, 28-36.

Grime J.P., Campbell B.D., Mackey J.M.L. and Crick J.C. (1991) Root plasticity, nitrogen capture and competitive ability. Special Publication of the British Ecological Society, 10, 381-397.

HaugGaARD-Nielsen H. and Jensen E.S. (2005) Facilitative root interactions in intercrops. Plant and Soil, 274, 237-250.

Hauggaard-Nielsen H., Ambus P. and Jensen E.S. (2001a) Interspecific competition, $N$ use and interference with weeds in pea-barley intercropping. Field Crops Research, 70, 101-109.

Hauggaard-Nielsen H., Ambus P. and Jensen E.S. (2001b) Temporal and spatial distribution of roots and competition for nitrogen in pea-barley intercrops - a field study employing ${ }^{32} \mathrm{P}$ technique. Plant and Soil, 236, 63-74.

Hauggaard-Nielsen H., Ambus P. and Jensen E.S. (2003) The comparison of nitrogen use and leaching in sole cropped versus intercropped pea and barley. Nutrient Cycling in Agroecosystems, 65, 289-300.

HeR BeRT S.J. (1977) Growth and grain yield of Lupinus albus at different plant populations. New Zealand Journal of Agricultural Research, 20, 459-465.

Huyghe C. (1991) Winter growth of autumn-sown white lupin (Lupinus albus L.): main-apex growth model. Annals of Botany, 67, 429-434.

IzaurRalde R.C., McGill W.B. and Juma N.G. (1992) Nitrogen fixation efficiency, interspecies $\mathrm{N}$ transfer, and root growth in barley field pea intercrop on a black chemozemic soil. Biology and Fertility of Soils, 13, 11-16.

JANNASCH R.W. and MARTIN R.C. (1999) The potential for capturing the forage yield of white lupin by intercropping with cereals. Biological Agriculture and Horticulture, 17, 113-130.

JENSEN E.S. (1996a) Barley uptake of N deposited in the rhizosphere of associated field peas. Soil Biology and Biochemistry, 28, 159-168.

Jensen E.S. (1996b) Grain yield, symbiotic $\mathrm{N}_{2}$-fixation and interspecific competition for inorganic $\mathrm{N}$ in pea-barley intercrops. Plant and Soil, 182, 25-38.

Karpenstein-Machan M. and Stuelpnagel R. (2000) Biomass yield and nitrogen fixation of legumes monocropped and intercropped with rye and rotation effects on subsequent maize crop. Plant and Soil, 218, 215-232.

Keating B.A. and CARberRy P.S. (1993) Resource capture and use in intercropping: solar radiation. Field Crop Research, 34, 273-301.

Keddy P.A. (1989) Competition. London, UK: Chapman and Hall.

Kurdali F., Sharabi N. and Arslan A. (1996) Rain-fed vetch-barley mixed cropping in the Syrian semi-arid conditions. Plant and Soil, 183, 137-148.

Li L., Sun J., Zhang F., Guo T., Bao X., Smith F.A. and Sмiтн S.E. (2006) Root distribution and interactions between intercropped species. Oecologia, 147, 280-290.
Lithourgidis A.S., Vasilakoglou I.B., Dhima K.V., Dordas C.A. and Yiakoulaki M.D. (2006) Forage yield and quality of common vetch mixtures with oat and triticale in two seeding ratios. Field Crops Research, 99, 106-113.

Mariotti M., Masoni A., Ercoli L. and Arduini I. (2006) Forage potential of winter cereal/legume intercrops in organic farming. Italian Journal of Agronomy, 3, 403-412.

MARTin M.P.L.D. and Field R.J. (1984) The nature of competition between perennial ryegrass and white clover. Grass and Forage Science, 39, 247-253.

Martin M.P.L.D. and Snaydon R.W. (1982) Root and shoot interactions between barley and field beans when intercropped. Journal of Applied Ecology, 19, 263-272.

McKenzie D.B. and Spaner D. (1999) White lupin: an alternative to pea in oat-legume forage mixtures grown in Newfoundland. Canadian Journal of Plant Science, 79, $43-47$.

Midmore D.J. (1993) Agronomic modification of resource use and intercrop productivity. Field Crops Research, 34, 357-380.

Mitchell C.E., Tilman D. and Groth J.V. (2002) Effects of grassland plant species diversity, abundance and composition on foliar fungal disease. Ecology, 83, 1713-1726.

Ofori F. and Stern W.R. (1987) Cereal-legume intercropping systems. Advances in Agronomy, 41, 41-89.

Papastylianou I. (2004) Effect of rotation system and N fertilizer on barley and common vetch grown in various crop combinations and cycle lengths. Journal of Agricultural Science, Cambridge, 142, 41-48.

Papastylianou I. and Danso S.K.A. (1991) Nitrogen fixation and transfer in vetch and vetch-oats mixtures. Soil Biology and Biochemistry, 23, 447-452.

Robinson R.C. (1969) Annual legume:cereal mixtures for forage and seed. Agronomy Journal, 61, 759-761.

SATORRE E.H. and SNAYdon R.W. (1992) A comparison of root and shoot competition between spring cereals and Avena fatua L. Weed Research, 32, 45-55.

Schmidtike K., Neumann A., Hof C. and Rauber R. (2004) Soil and atmospheric nitrogen uptake by lentil (Lens culinaris Medik.) and barley (Hordeum vulgare ssp. nudum L.) as monocrops and intercrops. Field Crops Research, 87, 245-256.

Schreiber M.M. (1967) A technique for studying weed competition in forage legume establishment. Weeds, $\mathbf{1 5}$, $1-4$.

Senaratne R., Liyanage N.D.L. and Ratnasinghe D.S. (1993) Effect of K on nitrogen fixation of intercrop groundnut and the competition between intercrop groundnut and maize. Fertilizer Research, 34, 9-14.

Shipley B. and Meziane D. (2002) The balanced-growth hypothesis and the allometry of leaf and root biomass allocation. Functional Ecology, 16, 326-331.

Sinclair T.R. and HorRie T. (1989) Leaf nitrogen, photosynthesis and crop rotation use efficiency: a review. Crop Science, 29, 90-98.

Sinoquet H. and Caldwell R.M. (1995) Estimation of light capture and partitioning in intercropping systems. 
In: Sinoquet H. and Cruz P. (eds) Ecophysiology of tropical intercropping, pp. 79-97. Paris, France: INRA.

SNAYD ON R.W. (1991) Replacement or additive designs for competition studies? Journal of Applied Ecology, 28, 930-946.

SNedecor G.W. and Cochran W.G. (1980) Statistical methods, 7th edn. Ames, IA: Iowa State University Press.

StRydhorst S.M., King J.R. and Lopetinsky K.J. (2008) Growth analysis of faba bean and lupin with volunteer barley competition in a northern environment. Agronomy Journal, 100, 1033-1038.

Suong T.T., Hutson J. and Schuller K.A. (2005) Mixed culture of wheat (Triticum aestivum L.) with white lupin (Lupinus albus L.) improves the growth and phosphorus nutrition of wheat. Plant and Soil, 272, 143-151.

Thorsted M.D., Weiner J. and Olesen J.E. (2006) Above- and below-ground competition between intercropped winter wheat Triticum aestivum and white clover Trifolium repens. Journal of Applied Ecology, 43, 237-245.

Tilman D. (1988) Plant strategies and the dynamics and structure of plant communities. Princeton, NJ: Princeton University Press.

Tofinga M.P., Paolini R. and Snaydon R.W. (1993) A study of root and shoot interactions between cereals and peas in mixtures. Journal of Agricultural Science, Cambridge, 120, 13-24.
Trenbath B.R. (1974) Biomass productivity of mixtures. Advances in Agronomy, 26, 177-210.

Unkovich M.J. and Pate J.S. (2000) An appraisal of recent field measurements of symbiotic $\mathrm{N}_{2}$ fixation by annual legumes. Field Crops Research, 65, 211-228.

VANDERMEER J.H. (1989) The ecology of intercropping. Cambridge: Cambridge University Press.

Willey R.W. and Osiru D.S.O. (1972) Studies on mixtures of maize and beans (Phaseolus vulgaris) with particular reference to plant population. Journal of Agricultural Science, Cambridge, 79, 519-529.

WiLson J.B. (1988) Shoot competition and root competition. Journal of Applied Ecology, 25, 279-296.

Wilson S.D. and Tilman D. (1993) Plant competition and resource availability in response to disturbance and fertilization. Ecology, 74, 599-611.

Wilson S.D. and Tilman D. (1995) Competitive responses of eight old-field plant species in four environments. Ecology, 76, 1169-1180.

Withers N.J. (1979) Effects of water stress on Lupinus albus. New Zealand Journal of Agricultural Research, 22, 445-474.

Xiao Y., Li L. and Zhang F. (2004) Effect of root contact on interspecific competition and $\mathrm{N}$ transfer between wheat and faba bean using direct and indirect ${ }^{15} \mathrm{~N}$ techniques. Plant and Soil, 262, 45-54.

Zadoks J.C., Chang T.T. and KonzaK C.F. (1974) A decimal code for the growth stages of cereals. Weed Research, 14, 415-421. 